\title{
Human and ecotoxicological impacts assessment from the Mexican oil industry in the Coatzacoalcos region, as revealed by the USEtox ${ }^{\mathrm{TM}}$ model
}

\author{
M. A. Morales-Mora • B. Rodríguez-Pérez • \\ S. A. Martínez-Delgadillo • E. Rosa-Domínguez • \\ C. Nolasco-Hipólito
}

Received: 14 October 2013 / Accepted: 20 April 2014 / Published online: 21 May 2014

(C) Springer-Verlag Berlin Heidelberg 2014

\begin{abstract}
Human and ecotoxicological impacts were analyzed in the lower basin of the Coatzacoalcos River (Veracruz, State in Mexico). High pollution levels of contaminants from the oil industry have been reported in natural streams and the Coatzacoalcos River and in their sediments. USEtox ${ }^{\mathrm{TM}}$ model was employed to evaluate environmental fate, exposure, and effect of nine organic compounds (polycyclic aromatic hydrocarbons and one of which was in the group of polychlorinated biphenyls), a heavy metal (lead), and the effect of the industrial wastewater emitted into the river, on the Coatzacoalcos region. Most of these compounds are highly toxic; they bioaccumulate
\end{abstract}

\section{Responsible editor: Philippe Garrigues}

M. A. Morales-Mora $(\bowtie)$

Subgerencia de Protección Ambiental, PEMEX-Petroquímica, Jacarandas 100, Colonia Rancho Alegre, Coatzacoalcos, Veracruz 96558, México

e-mail: miguel.angel.moralesmo@pemex.com

B. Rodríguez-Pérez

Industrial Engineering Department, University of Cienfuegos,

Carretera a Rodas 4 Caminos, Cienfuegos 55200, Cuba

e-mail: brguez@ucf.edu.cu

S. A. Martínez-Delgadillo

Departamento de Ciencias Básicas, Universidad Autónoma

Metropolitana-Azcapotzalco, Avenida San Pablo 180, Azcapotzalco,

D.F. 02200, Mexico

e-mail: samd@correo.azc.uam.mx

\section{E. Rosa-Domínguez}

Chemistry-Pharmacy Faculty, Central University Marta Abreu de Las Villas, Camajuaní Road km 51⁄2, Santa Clara, Villa Clara 54830, Cuba

e-mail: erosa@uclv.edu.cu

C. Nolasco-Hipólito

Faculty of Resource Science and Technology, University Malaysia

Sarawak, Kota Samarahan 94300, Malaysia

e-mail: hcnolasco@frst.unimas.my in human and animal tissue, mainly in the fatty tissues and can damage different organs and systemic targets such as the liver, kidney, hormonal system, nervous system, etc., of both humans and wildlife. The model estimates that $96 \%(3,247 \mathrm{~kg} /$ day $)$ of organic compounds is transferred from the water into air, whereas only $4 \%$ (151 kg/day) remains in the water. In addition, it predicts that humans are mainly exposed to polychlorinated biphenyls (PCBs) congeners (28 and 153) by eating contaminated fish, due to PCBs accumulating in the fish fat tissue. The number of cases of cancer and noncancer (1 in 862 habitants per additional kilogram) is expected to have an increment due to the higher PCBs exposure of human population. Genetic damages in fishes, earthworms, and toads have been observed and related to higher exposure to organic compounds. The relationship between the field reported data and those one predicted by the USEtox ${ }^{\mathrm{TM}}$ model have been confirmed empirically by using the nonparametric correlation analysis (Spearman's rho). Based on the USEtox model, the environmental stress in the Coatzacoalcos industrial zone is between 2 and 6 orders of magnitude over geometric mean of acute aquatic $\mathrm{EC}_{50} \mathrm{~s}$. We think that USEtox model can be used to expand the number of substances that have the current water quality guidelines to improve the water management in Mexico.

Keyword Comparative toxic units $\cdot$ Characterization factors · Petrochemicals $\cdot$ Yuribia dam

\section{Introduction}

Coatzacoalcos and Minatitlán are two nearby cities alongside the Coatzacoalcos River, at the Golf of Southeast Mexico, both with about 463,100 inhabitants (INEGI 2010). Since the 1960 s, the oil and petrochemical industry were developed in the Coatzacoalcos region. Nowadays, there are more than 65 